\title{
Feeding ecology of the mangrove oyster, Crassostrea gasar (Dautzenberg, 1891) in traditional farming at the coastal zone of Benin, West Africa
}

\author{
Alphonse Adite ${ }^{1 *}$, Stanislas P. Sonon ${ }^{1}$, Ghelus L. Gbedjissi ${ }^{2}$ \\ ${ }^{1}$ PRECOB, Unité de Recherches sur les Zones Humides (URZH), Département de Zoologie, Faculté des Sciences et Techniques, \\ Université d’Abomey-Calavi, Cotonou, Bénin; 'Corresponding Author: alphonseadite@gmail.com \\ ${ }^{2}$ Laboratoire de Parasitologie \& Ecologie Parasitaire, Département de Zoologie, Faculté des Sciences et Techniques, Université \\ d’Abomey-Calavi, Cotonou, Bénin
}

Received 27 October 2013; revised 27 November 2013; accepted 4 December 2013

Copyright (c) 2013 Alphonse Adite et al. This is an open access article distributed under the Creative Commons Attribution License, which permits unrestricted use, distribution, and reproduction in any medium, provided the original work is properly cited. In accordance of the Creative Commons Attribution License all Copyrights @ 2013 are reserved for SCIRP and the owner of the intellectual property Alphonse Adite et al. All Copyright @ 2013 are guarded by law and by SCIRP as a guardian.

\section{ABSTRACT}

Wild collection management and farming of the mangrove oyster (Crassostrea gasar) occurring widely at the Benin (West Africa) coastal zone require knowledge on the feeding ecology to explore energy sources and nutritional needs. Six hundred thirty (630) individuals of $C$. gasar have been sampled in the rearing site at the Benin coastal lagoon to investigate on the trophic ecology of this cultivated bivalve. The diet analysis revealed that $C$. gasar is a filter-feeder foraging mainly on phytoplankton $(\mathbf{7 2 . 7 0 \% )}$ and substrate particles $(22.95 \%)$. This trophic specialization results from anatomical structure, mainly the presence of gills which facilitate the filtering of number of plankton taxa. Dominant phytoplanktons ingested comprised of Diatomophycea (33.52\%), Chlorophycae (17.19\%), Scenedesmacae (13.80\%), Dictyosphaeriacae (3.79\%), and Pleurococcacae (2.75\%). Eight genuses of phytoplankton, Polycystis, Coelosphaerium, Protococcus, Botryoccocus, Crucigenia, Melosira, Cyclotella, and Gyrosigma dominated the diet of $C$. gasar with aggregated volumetric proportions reaching $69.06 \%$ of the diet. Higher occurrences were recorded mainly for Melosira occurring in 263 (41.75\%) stomachs, substrate particles in 211 (33.49\%), and Polycystis in 151 (23.97\%). C. gasar exhibited a high niche breadths varying from 4.54 to 5.78 , suggesting that this bivalve consumed a high variety of food items, thus exhibiting a degree of trophic plasticity. Diet overlaps $\left(\varnothing_{j k}\right)$ among different size classes were high and varied from
0.71 to 0.98 , indicating an ontogenetic diet shift pattern in C. gasar. Probably, to adapt to the benthic-muddy environment and to increase survival, C. gasar has evolved a specialized feeding mechanism and strategy to retrieve only needed nutrients for growth and to reject awful and nondigestible foods. Also, at the oyster rearing grounds, there is an evidence of shift in the food web structure leading to an increase of the biological productivity at the coastal zone. The output from this study is a valuable documentation for the sustainable development of oyster aquaculture, wild stock management and conservation. However, further scientific knowledge on nutritional needs, phytoplankton toxicity and habitat degradation, and improvement of farming techniques are required for an integrated oyster management.

Keywords: Conservation; Crassostrea; Diet Overlaps; Farming; Filter-Feeder; Food Web; Foraging Strategy; Phytoplankton

\section{INTRODUCTION}

Shellfish and particularly oysters are valuable food for human health and contain about $80 \%$ of water, $17.2 \%$ of protein, and many vitamins such as A, D, E, B1, B2, B6, B12, C etc., and minerals that satisfy human nutritional needs [1]. In artisanal and commercial fisheries, Crassostrea is massively harvested by grass-roots for food, sales and their shells as ingredient for animal food industries [2-4]. In traditional and modern aquaculture, this genus belongs to one of the most cultivated species of mol- 
lusks to supply food needs and to provide sustainable resources for grass-roots [5]. Compared to fishes, shellfish like oysters exhibit an efficient rate of conversion of primary production as well as a relatively low cost of rearing [5]. With regards to its ecological importance, Crassostrea stands out as an indicator of environmental quality and measures the degree of contamination of aquatic ecosystems, since it accumulates polluting substances that lead to chromosomal changes and mutations [6]. In addition to improving the quality of polluted water, oysters contribute to reducing ocean and coastal waters acidification because of the continuous absorption of anthropogenic $\mathrm{CO}_{2}$ [6].

The mangrove oysters of the genus Crassostrea are bivalve mollusk belonging to the Lamellibranchs class, Dysonta Order and Ostreidae family $[7,8]$. This bivalve occurs throughout the world and over 54 species make up the genus [7-9]. Most cultivated species, the Pacific oyster, C. gigas, are native in Japan, while the Portuguese oyster, C. angulata, the Eastern oyster, C. virginica, the Brazilian oyster, C. rhizophorae, and C. gasar occur most in west African coastal zones.

In the southern region of Benin, shellfish, particularly C. gasar are of great economic importance and provide sustainable financial resources for grass-roots population through wild collections and traditional farming $[10,11]$. In Benin, C. gasar occurs in coastal lagoons, brackish water lakes and in estuarine areas of depth between 0 and $40 \mathrm{~m}$. Preferred habitats are bottom substrates such as rocks, shells, debris, mud and sands [2, 12,13].

However, despite its economic and social importance in Benin, very little is known about the ecology of this species which appears to be an important source of protein and revenues for the population inhabiting the Benin coastal area [14,15].

Particularly, shellfish, such as Crassostrea, have been overlooked and neglected by the modern aquaculture and nothing is known about the feeding ecology of this bivalve in the wild and in traditional farming at the Benin coastal zone. To develop the oyster aquaculture and to better manage the wild population, there is a need to provide scientific information on the trophic ecology of this species to evaluate energy sources for biological function such as reproduction, growth etc. Like many shellfish, Crassostrea is a filter-feeder [9,16,17], extracting and selecting particles of organic and inorganic detritus from the aquatic environment and rejecting unwanted foods $[18,19]$.

This research seeks to investigate on the feeding ecology of C. gasar rearing at the coastal lagoon of Benin, in order to contribute to filling the gap in our knowledge of this economically important bivalve and to contribute for its sustainable management. Specifically, the study aims to investigate on 1) the diet composition at the rearing site, 2) the ecological niche, 3) the diet overlap between size classes and the ontogenetic diet shift, and 4) implications for fisheries, species conservation and aquaculture.

\section{MATERIAL AND METHODS}

\subsection{Study Sites}

The study site is the coastal lagoons (Southern Benin) located between $06^{\circ} 19^{\prime} 36.2^{\prime \prime} \mathrm{N}$ and $002^{\circ} 03$ '38.3"E, covers $30 \mathrm{~km}^{2}$ with about $60 \mathrm{~km}^{2}$ of swamps and extend on 130 $\mathrm{km}$ (Figure 1). The coastal area is a brackish water with salinity (0 g/l - $35 \mathrm{~g} / \mathrm{l})$ regulated by the flooding of the Mono River $(527 \mathrm{~km})$. This river supports a hydro electrical dam which greatly affects the hydrological regime and the biological resources of the coastal waters [6]. The climate comprises two wet seasons (April to July; mid-September to October) and two dry seasons (December to March; mid-August to mid-September). Annual mean rainfall is about $1307.3 \mathrm{~mm}$ [20]. Ambient temperatures vary between $25^{\circ} \mathrm{C}$ and $27.7^{\circ} \mathrm{C}$. Though very diverse, the plant communities at the coastal zone are dominated by mangrove species such as Rizophora racemosa and Avicennia Africana which are now being intensively degraded for domestic use such as firewood. Also, some sea grasses, such as Cyperus articulates and Paspalum vaginatum are common. Some plantations of Coco nucifera and Elaeis guineensis (palm-tree) are present in the plant community of the coastal zone and exploited for food and oil. Multi-species fisheries targeted to dominant fish families such as Cichlidae, Mugilidae, Eleotridae, Bagridae, Clupeidae, Crustacean (shrimps, crabs) dominate the coastal area. Particularly, at the coastal zone, oyster fisheries and traditional oyster farming are permanent main activities of the women.

\subsection{Rearing Site}

The rearing site has been selected at Dégouè Village (Ouidah city) of the coastal zone, where intense oyster farming take place. A site of $18 \mathrm{~m}^{2}(3 \mathrm{~m} \times 6 \mathrm{~m})$ have been selected at the rearing location adjacent to the fishermen houses and bordered with sticks. The rearing ground is settled at about 100 meters from fishermen houses, in a shallower and sandy-muddy location, with depth, transparencies, temperature and salinity between $40.9-70 \mathrm{~cm}, 40.9-70 \mathrm{~cm}, 26.6^{\circ} \mathrm{C}-31.7^{\circ} \mathrm{C}$ and $0 \mathrm{~g} / \mathrm{l}-$ $18 \mathrm{~g} / \mathrm{l}$, respectively. $\mathrm{pH}$ and dissolved oxygen averaged $6.59 \pm 1.29$ and $5.28 \pm 1.06 \mathrm{mg} / \mathrm{l}$, respectively. These water characteristics exhibited significant variations $(\mathrm{P}<$ 0.05) during the rearing periods and the values recorded fulfilled the requirement for potential growth of C. gasar. Rearing followed traditional techniques (seeds collection, seeds stocking, spreading, growth control, harvesting) [6]. 


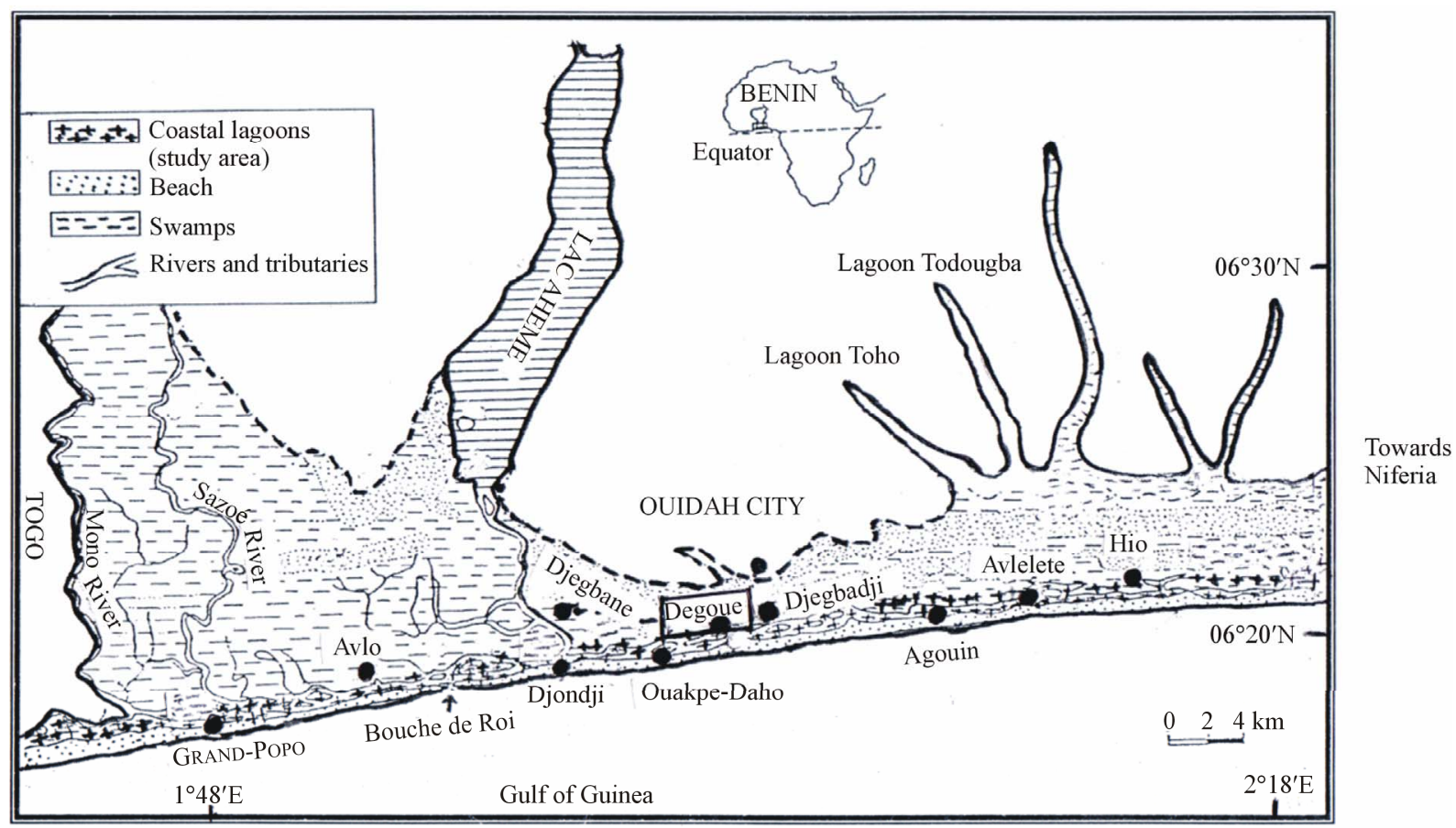

Figure 1. Map showing the locations (villages) where Crassostrea gasar farming occurs at the Benin's coastal lagoon. Oyster sampling for diet study has been done at Degoue village (Ouidah City).

The juvenile oysters, seeds of 2 months-old, used for the traditional farming were collected from the reproduction grounds of salinity between $25 \mathrm{~g} / \mathrm{l}$ and $35 \mathrm{~g} / \mathrm{l}$ and adjacent to the sea. The seeds of $C$. gazar were then transported with boats to the rearing grounds at Degouè village. For this research 15,600 seeds of 2 months-old (mean total length $=35.11 \mathrm{~mm}$; mean weight $=5.79 \mathrm{~g}$ ) has been evenly distributed (stocked) on the rearing site at a density of $500 / \mathrm{m}^{2}$. To enhance oxygen and nutrient consumption for better growth, aggregated oysters and those covered by mud were spread every 2 months at the rearing site. As an extensive aquaculture, rearing of C. gasar was done under natural conditions and without food supply.

\subsection{Oyster Sampling}

To analyze the stomach contents, sampling of C. gasar was done after ten (10) months of rearing which corresponded to oysters of twelve months-old. At the rearing ground, the oyster sampling was performed in such a way to get representative samples. Indeed, the $18 \mathrm{~m}^{2}$ was divided in six (6) compartments of $3 \mathrm{~m}^{2}$. One hundred five juveniles (105 seeds) were randomly sampled on each compartment to have a total of 630 specimens of oyster for the dietary analysis. Once the specimens sampled, they were immediately preserved in situ in $90 \%$ ethanol. To allow better entrance of the alcohol and better preservation of the flesh and gut contents, the two valves (shells) of each specimen were slightly opened.

\subsection{Stomach Content Analysis}

Specimens were brought to the laboratory and twentyfour hours after preservation, individuals were measured for total length (TL), maximum width (W), maximum height $(\mathrm{H})$ and total weight (TW). TL, W, and $\mathrm{H}$ have been measured with a vernier caliper ruler to the nearest $1 \mathrm{~mm}$. TW have been measured with an electronic scale (Philips) to the nearest $0.1 \mathrm{~g}$. The valves were then separated and the gut was opened and all the stomach contents were removed and spread on a glass slide for examination first under a binocular (model: Pierron). To identify the phytoplankton, a sub-sample of known volume of the stomach contents was taken and the total gross volume was estimated by water displacement using an appropriately sized graduated cylinder. The sub-sample is then examined under a photonic microscope. Preys were identified to the lowest possible taxonomic level using the identification keys of Needham (1962) [21]. After identification, each food item of the sub-sample was separated, counted and the volumetric percentage of each prey was estimated for the sub-sample and then for the total gross stomach content [22].

\subsection{Data Analysis}

Volumetric, numeric and occurrence data has been recorded on Excel software spreadsheet. Volumetric proportions of each food item ingested by C. gasar were computed following the formula: 


$$
\mathrm{Pi}=\left(\sum_{i=1}^{n} \mathrm{vi}\right) / \mathrm{Vt}
$$

where $p_{i}$ is the proportion of food item $i$ in the diet, $n$ is the number of stomachs, vi is the volume of food item $i$ in a single stomach, $\mathrm{Vt}$ is the total volume of food ingested by $n$ stomachs (in this study, $n=630$ stomachs).

Also, volumetric proportions of each food item ingested were computed for different sizes classes of $C$. gasar to explore ontogenetic diet shift.

Diet breadth was calculated following Simpson's (1949) niche breadth formula [23,24]:

$$
\text { Niche breadth }(\mathrm{B})=1 / \sum_{i=1}^{n} \mathrm{p}_{i}^{2}
$$

where $p_{i}$ is the proportion of food item $i$ in the diet, and $n$ is the total number of food items in the diet. $B$ ranges from 1 , when only one resource is used, to $n$, when all resources are consumed in equal proportions.

The values of computed indices were submitted to oneway analysis of variances (ANOVA) using SPSS software computer program [25].

Niche overlap was calculated using Pianka's (1994) overlap index (Ø) [26]:

$$
\varnothing_{j k}=\frac{\sum_{i=1}^{n} P_{i j} P_{i k}}{\left(\sum_{i=1}^{n} P_{i j}^{2} \times \sum_{i=1}^{n} P_{i k}^{2}\right)^{1 / 2}}
$$

where $\varnothing_{j k}$ is dietary overlap between species $j$ and species $k, P_{i j}$ is the proportion of resource $i$ used by species $j$, $P_{i k}$ is the proportion resource $i$ used by species $k$, and $n$ is the number of resource categories utilized.

\section{RESULTS}

\subsection{Growth and Population Structure of $C$. gasar at the Rearing Ground}

Oyster sampling for dietary study has been done during the flooding period, after 10 months of rearing, corresponding to 12 months-old oysters. The sample was a mixture of juveniles (53.33\%) and adults (46.67\%) with total length, width, and height averaging $54.38 \mathrm{~mm}$ (range: 18 - $98 \mathrm{~mm}$ ), $36.07 \mathrm{~mm}$ (range: 18 - $71 \mathrm{~mm}$ ), $17.60 \mathrm{~mm}$ (range: 7 - $33 \mathrm{~mm}$ ) respectively (Table 1). Total weight ranged from 3.3 - $66.4 \mathrm{~g}$ (mean: $21.36 \mathrm{~g}$ ) and mean monthly growths were moderate (Table 1). The size structure of $C$. gasar for total length exhibited unimodal distribution (Figure 2).

\subsection{Diet Composition and Occurrence}

Volumetric proportions: Table 2 shows the different food items ingested by C. gasar reared at the Benin coastal zone along with their volumetric, numeric and occurrence percentages. Of a total of 630 stomachs examined, 20.16\% (127 specimens) have empty stomachs. The dominant food items identified in the diet of C. gasar were phytoplankton (72.70\%) and substrate particles (22.95\%) and the minor preys recorded were detritus (1.48\%) and protozoans (0.01\%). Phytoplankton was composed of 30 genus belonging to 8 families (Figures 3 and 4) such as Diatomophycea (33.52\%), the most speciose family in the diet, comprising Melosira, Stephanodiscus, Cyclotella, Cocconeis, Frustulia, Gyrosigma, navicula, Cymbella, Amphora, Fragilaria, Nitztchia, Campylodiscus, Gomphonema, Epithemia, Diatoma, Synedra, Ajchnanthes, Closterium, Anomoconeis, Chlorophycae (17.19\%) comprising Polycystis (17.12\%), Oxilatoria (0.02\%) and Sphaerocystis (0.05\%), Scenedesmacae comprising Crucigenia (13.77\%) and Scenedesmus (0.03\%), Dictyosphaeriacae

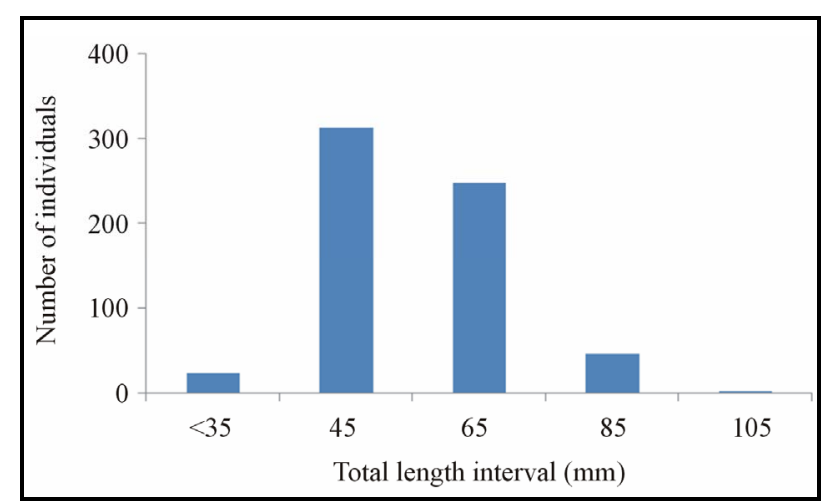

Figure 2. Size structure of Crassostrea gasar (12 months-olds) reared from January to October 2012 at the Benin's coastal lagoon. $\mathrm{N}=630$ individuals.

\begin{tabular}{|c|c|c|c|c|c|c|c|}
\hline \multirow{2}{*}{ Growth factors } & \multicolumn{3}{|c|}{$\begin{array}{c}\text { Initial } \\
\text { (3 months old) }\end{array}$} & \multicolumn{3}{|c|}{$\begin{array}{c}\text { Final } \\
\text { (12 months old) }\end{array}$} & \multirow{2}{*}{$\begin{array}{l}\text { Mean monthly } \\
\text { growth }\end{array}$} \\
\hline & Mean & Range & STDV & Mean & Range & STDV & \\
\hline Total length (mm) & 35.11 & $43-55$ & 4.95 & 54.38 & $18-98$ & 12.88 & 2.14 \\
\hline Width (mm) & 25.96 & $12-38$ & 3.51 & 36.07 & $18-71$ & 7.16 & 1.12 \\
\hline Height (mm) & 13.18 & $0.9-12$ & 2.51 & 17.60 & $7-33$ & 4.58 & 0.49 \\
\hline Total weight (g) & 5.79 & $1.53-8.9$ & 2.20 & 21.36 & $3.3-66.4$ & 12.01 & 1.73 \\
\hline
\end{tabular}

Table 1. Mean values $(n=630)$, ranges, and standard of deviation (STDV) of the growth factors of Crassostrea gasar reared from January to October 2012 at the Benin's coastal lagoon. 


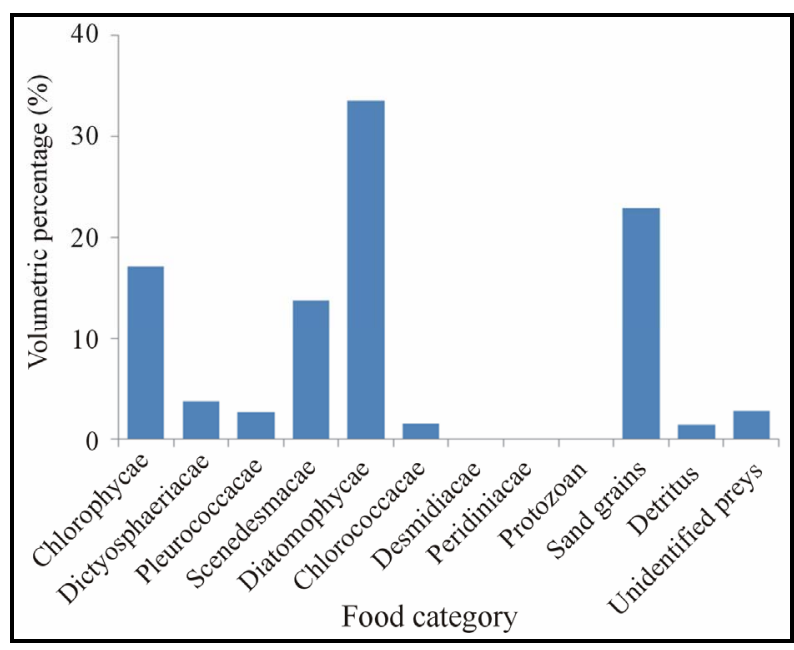

Figure 3. Volumetric percentage (\%) of food ingested by Crassostrea gasar reared from January to October 2012 at the Benin's coastal lagoon.

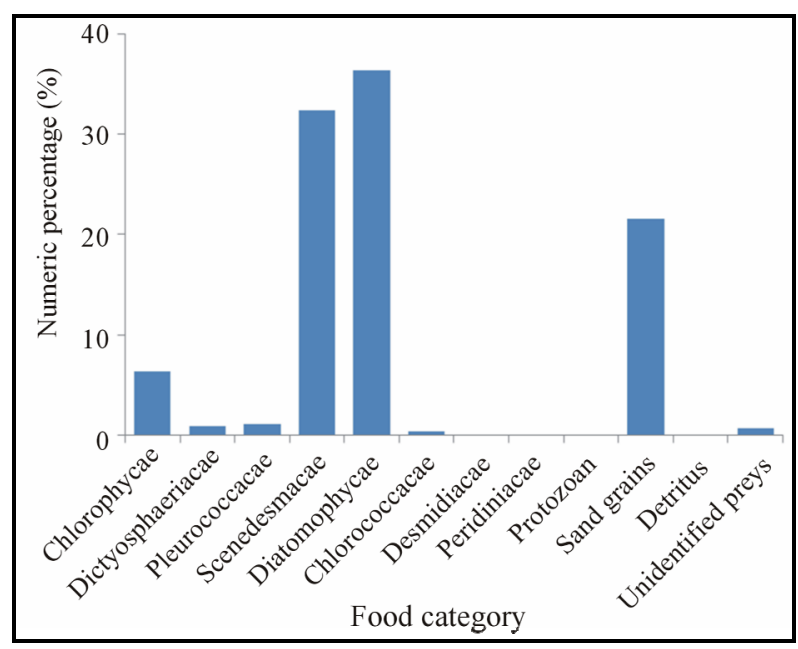

Figure 4. Numeric percentage (\%) of food ingested by Crassostrea gasar reared from January to October 2012 at the Benin's coastal lagoon.

represented by Botryoccoccus (3.79\%), Pleurococcacae represented by Protococcus (2.75\%). The least consumed phytoplankton were Chloroococcacae (1.57\%) represented by Coeulosphaerium (1.54\%) and Dictyosphaerium $(0.033 \%)$, Desmidiacae represented by Euastrium $(0.03 \%)$ and Peridiniacae represented by Peridinium (0.04\%).

As a result, eight (8) genus of phytoplankton, Polycystis, Coelosphaerium, Protococcus Botryoccocus, Crucigenia, Melosira, Cyclotella, and Gyrosigma dominated the diet of $C$. gasar with aggregated volumetric proportions reaching $69.06 \%$ of the diet (Table 2). Also, the numeric proportions of diet follow approximately the same trends with the same genus of phytoplanktons (Polycystis, Coelosphaerium, Protococcus Botryoccocus, Crucigenia, Melosira, Cyclotella, Gyrosigma) dominating the stom- achs contents with aggregated numeric proportion of 76.97\% (Table 2).

Diet occurrence: Of the 33 foods items recorded, the ten (10) first preys with relatively higher occurrence were Melosira (Diatomophycae) occurring in 263 (41.75\%) stomachs, substrate particles occurring in 211 (33.49\%) stomachs, Polycystis (Chlorophycae) occurring in 151 (23.97\%), Crucigenia (Scenedesmacae) found in $63(10 \%)$ stomachs, Cyclotella (Diatomophycae) found in 60 (9.52\%) stomachs, Navicula (Diatomophycae) in 58 (9.21\%) stomachs, Gyrosigma (Diatomophycae) in 53 (9.21\%) stomachs, Botryoccocus (Dictyosphaeriacae) in 51 (8.09\%) stomachs, Frustulia (Diatomophycae) in 39 (6.19\%) stomachs, Protococcus (Pleurococcacae) in 34 (5.39\%), and Coelosphaerium (Chloroococcacae) occurring in 23 stomachs (3.65\%) (Table 2, Figure 5). The lowest occurrences of $0.16 \%$ ( 1 stomach) were recorded for Diatoma, Synedra, Anomoconeis (Diatomophycae) and for Stentor (Protozoan), Euastrum (Desmidiacae) and Dictyosphaerium (Chlorococcacae), respectively.

\subsection{Niche Breadth}

At the Benin coastal zone, C. gasar exhibited some relatively high niche breadths varying between 4.54 and 5.78 suggesting that this bivalve consumed a high variety of food items. In general, there is significant $(p<0.05)$ variation in the niche breadth of $C$. gasar and individuals of higher size tend to have high niche breadths and those of lower size had relatively low niche breadths (Figure 6).

\subsection{Niche Overlap and Ontogenetic Diet Shift}

Pairwise niche overlaps $\left(\varnothing_{j k}\right)$ computed from volumetric proportion of diet among different size classes were high and vary between 0.71 and 0.98 (Table 3). Overall, there is significant $(\mathrm{p}<0.05)$ variation in the niche overlaps of $C$. gasar from the coastal zone. Also, volumetric proportions of diet indicated that oysters of small sizes (sizes $<35 \mathrm{~mm}$ and between 35 - $55 \mathrm{~mm}$ ) tended to feed primarily on Polycystis (Chlorophycea) (28\% $30 \%$ ) and larger individuals (55 - $115 \mathrm{~mm}$ ) consumed more Crucigenia (15\% - 29\%). On the contrary, the consumption of Melosira (Diatomophycea) (20.10\%, 19.9\%, 26.99\%, 23.65\% for sizes <35 mm, $35-55 \mathrm{~mm}, 55-75$ $\mathrm{mm}, 75-95 \mathrm{~mm}$, respectively) and substrate particles (26.80\%, 22.09\%, 24.84\%, 17.18\% for size $<35 \mathrm{~mm}, 35$ - 55, 55 - 75, 75 - 95, respectively) were relatively higher in all sizes classes.

\section{DISCUSSIONS}

Knowledge on feeding ecology of fishes and shellfishes species is of great interest both for fisheries mana- 


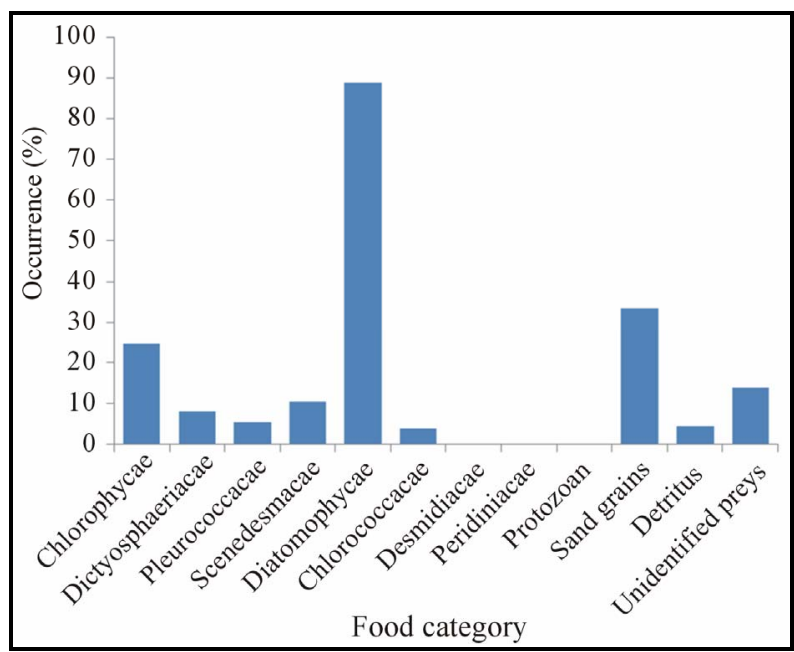

Figure 5. Percentage (\%) occurrence of food ingested by Crassostrea gasar reared from January to October 2012 at the Benin's coastal lagoon.

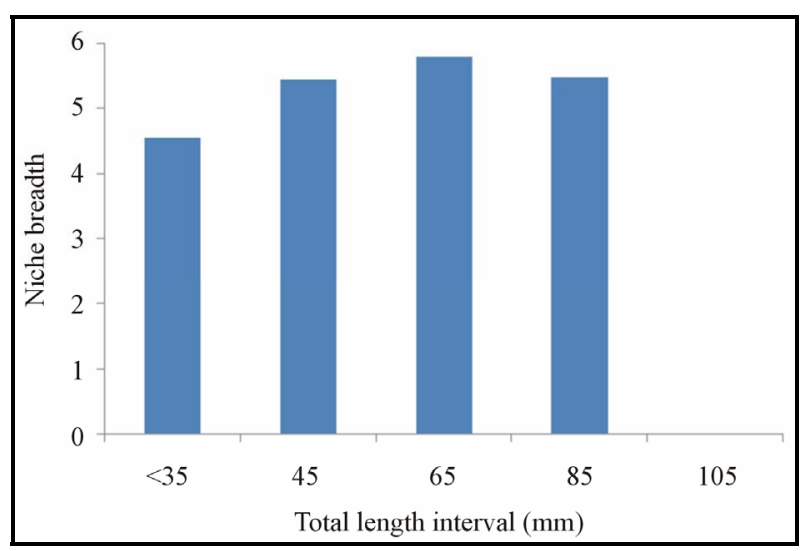

Figure 6. Niche breadth by size classes of Crassostrea gasar reared from January to October 2012 at the Benin's coastal lagoon.

gement and aquaculture [27-29]. Especially in aquaculture industries, information on food habit of a species is important to formulate appropriate dry food to satisfy nutritional need for rapid growth $[22,30]$.

The present investigation indicated that $C$. gasar ingested a variety of benthic and pelagic food resources, mainly phytoplankton (72.70\%) which consistently dominated the diet, suggesting that $C$. gasar is a planktinovore specialist. Though consuming about thirty (30) genus of phytoplankton, Melosira (Diatomophycae), Polycystis (Chlorophycae) and Crucigenia (Scenedesmacae) remained the dominant algae consumed and accounting for $23.77 \%, 17.19 \%$, and $13.77 \%$, respectively. This trophic specialization probably results from anatomical structure, mainly the presence of gills which facilitate the filtering of numeric phytoplankton taxa [31]. As reported by Newell and Langdon [32], in the water column, planktons and particles are drawn on the gills by the motion of small cilia. Once retained by the gills, the food are sorted, conducted by ciliary movement of mucous strings to the labial palps, and then transported to the mouth and stomach. Miossec et al. and Abgrall et al. [8,9] reported similar trends of phytoplankton filter-feeder habit for the pacific oyster, C. gigas and for the Eastern oyster, C. virginica feeding mainly on planktonic particles. Like $C$. virginica, C. gasar foraged mainly on diatom species of the genera Melosira, Cyclotella, Coccocenieis, Nitzschia and on Peridinium (Peridiniacae) [33,34]. Nevertheless, in the Benin coastal water, the presence of $22.95 \%$ of sand grains in the diet indicated the benthic-like foraging behavior of this species.

Of the 33 food items consumed by C. gasar, only ten occurred in a relatively high number of stomachs varying between 23 (3.65\%) stomachs for Coelosphaerium (Chloroococcacae) and 263 (41.75\%) stomachs for Melosira (Diatomophycae). Except sands grains which occurred in 211 (33.49\%) stomachs, phytoplankton species were the major food items occurring in most stomach.

The results revealed that $C$. gasar had a broader niche breadth varying between 4.54 and 5.78 (mean: 5.31). In general, the niche breadth increased with the size of $C$. gasar indicating that this species consumed a broader range of food resources (phytoplankton especially) as they growth [35-37]. Moreover, the results revealed that $C$. gasar exhibited an ontogenetic diet shift, a major feature of feeding ecology which shows size-related patterns of feeding [38-40]. Indeed, small sizes of $C$. gasar consumed more Polycystis (Chlorophycae) whereas larger individuals consumed more Crucigenia. However, the consumption of Melosira (Diatomophycae) and substrate particles were relatively higher in all sizes classes and consequently were not associated with sizes (Table 4). As a result, in addition to the less developed digestive tract, leading to ontogenetic diet shift [35], we hypothesize that C. gasar may have evolved the filtering feeding behavior and mechanisms to minimize potential food competition between juveniles and adults in order to optimize their existence.

The higher niche overlaps recorded and varying between $\varnothing_{j k}=0.71$ and $\varnothing_{j k}=0.98$, suggest a relatively high similarity between diet of two size classes. In general, individuals with adjacent size classes tended to have higher niche overlaps than pairings of distant size classes (Table 3). Again, this pattern is an indicator of ontogenetic diet shift in C. gasar [22,35,41].

Due to the large number of phytoplankton species (30 genus) ingested, C. gasar may exhibit a degree of trophic plasticity, thus, may shift his trophic structure according to the phytoplankton species available in the habitat [28, 42,43]. Indeed, despite the habitat heterogeneity and fragmentation caused by the destruction of mangrove 
Table 2. Volumetric and occurrence percentages (\%) of food items ingested by Crassostrea gasar reared from January to October 2012 at the Benin's coastal lagoon.

\begin{tabular}{|c|c|c|c|c|c|}
\hline Food category & Genus & $\begin{array}{c}\text { Volumetric } \\
\text { percentage }(\%)\end{array}$ & $\begin{array}{c}\text { Numeric } \\
\text { percentage (\%) }\end{array}$ & $\begin{array}{c}\text { Occurrence } \\
\text { (number) }\end{array}$ & $\begin{array}{c}\text { Percentage } \\
\text { occurrence (\%) }\end{array}$ \\
\hline \multirow[t]{3}{*}{ Chlorophycae } & Polycystis & 17.12 & 6.35 & 151 & 23.97 \\
\hline & Oxilatoria & 0.02 & 0.001 & 2 & 0.32 \\
\hline & Sphaerocystis & 0.05 & 0.03 & 2 & 0.32 \\
\hline Dictyosphaeriacae & Botryoccoccus & 3.79 & 0.99 & 51 & 8.09 \\
\hline Pleurococcacae & Protococcus & 2.75 & 1.16 & 34 & 5.39 \\
\hline \multirow[t]{2}{*}{ Scenedesmacae } & Scenedesmus & 0.03 & 0.01 & 3 & 0.47 \\
\hline & Crucigenia & 13.77 & 32.39 & 63 & 10 \\
\hline \multirow[t]{19}{*}{ Diatomophycae } & Melosira & 23.77 & 33.39 & 263 & 41.75 \\
\hline & Stephanodiscus & 0.2 & 0.09 & 4 & 0.63 \\
\hline & Cyclotella & 3.23 & 0.98 & 60 & 9.52 \\
\hline & Cocconeis & 0.55 & 0.06 & 19 & 3.01 \\
\hline & frustulia & 0.75 & 0.13 & 39 & 6.19 \\
\hline & Gyrosigma & 3.09 & 1.35 & 53 & 8.41 \\
\hline & Navicula & 0.92 & 0.17 & 58 & 9.21 \\
\hline & Cymbella & 0.16 & 0.01 & 7 & 1.11 \\
\hline & Amphora & 0.42 & 0.04 & 20 & 3.17 \\
\hline & Fragilaria & 0.06 & 0.02 & 8 & 1.27 \\
\hline & Nitztchia & 0.06 & 0.02 & 11 & 1.75 \\
\hline & Campylodiscus & 0.04 & 0.01 & 4 & 0.63 \\
\hline & Gomphonema & 0.03 & 0.01 & 3 & 0.48 \\
\hline & Epithemia & 0.09 & 0.01 & 3 & 0.48 \\
\hline & Diatoma & 0.02 & 0.001 & 1 & 0.16 \\
\hline & Synedra & 0.02 & 0.001 & 1 & 0.16 \\
\hline & Achnanthes & 0.03 & 0.01 & 3 & 0.48 \\
\hline & Closterium & 0.03 & 0.002 & 2 & 0.32 \\
\hline & Anomoconeis & 0.05 & 0.001 & 1 & 0.16 \\
\hline \multirow[t]{2}{*}{ Chlorococcacae } & Coelosphaerium & 1.54 & 0.36 & 23 & 3.65 \\
\hline & Dictyosphaerium & 0.033 & 0.011 & 1 & 0.16 \\
\hline Desmidiacae & Euastrum & 0.04 & 0.001 & 1 & 0.16 \\
\hline Peridiniacae & Peridinium & 0.037 & 0.001 & 2 & 0.32 \\
\hline Protozoan & Stentor & 0.02 & 0.001 & 1 & 0.16 \\
\hline Sand grains & & 22.95 & 21.54 & 211 & 33.49 \\
\hline Detritus & & 1.48 & 0.09 & 28 & 4.44 \\
\hline Unidentified preys & & 2.85 & 0.76 & 96 & 13.96 \\
\hline
\end{tabular}

Table 3. Matrix of niche overlaps $\left(\varnothing_{j k}\right)$ of Crassostrea gasar reared for from January to October 2012 at the Benin's coastal lagoon (South-Benin).

\begin{tabular}{ccccc}
\hline Size classes $(\mathbf{m m}$ TL) & $<35$ & $\mathbf{4 5}$ & $\mathbf{6 5}$ & $\mathbf{8 5}$ \\
\hline$<35$ & 1 & 0.98 & 0.88 & 0.75 \\
$\mathbf{4 5}$ & & 1 & 0.86 & 0.71 \\
$\mathbf{6 5}$ & & & 1 & 0.91 \\
$\mathbf{8 5}$ & & & & 1 \\
\hline
\end{tabular}

forest, this shellfish is still relatively well-established all the long of the coastal zone, probably, because of the tro- phic plasticity behavior and the planktinovore-like feeding strategy. 
Table 4. Volumetric percentages (\%) of food items ingested by size classes of Crassostrea gasar reared from January to October 2012 at the Benin's coastal lagoon (South-Benin).

\begin{tabular}{|c|c|c|c|c|c|c|}
\hline \multirow{2}{*}{ Food category } & \multirow{2}{*}{ Genus } & \multicolumn{5}{|c|}{ C. gasar size classes (mm TL) } \\
\hline & & $<35$ & 45 & 65 & 85 & 105 \\
\hline \multirow[t]{3}{*}{ Chlorophycae } & Polycystis & 29.90 & 28.97 & 10.94 & 6.84 & - \\
\hline & Oxilatoria & 0.00 & 0.00 & 0.03 & 0.00 & \\
\hline & Sphaerocystis & 0.00 & 0.14 & 0.00 & 0.00 & \\
\hline Dictyosphaeriacae & Botryoccoccus & 1.03 & 4.74 & 3.27 & 3.53 & \\
\hline Pleurococcacae & Protococcus & 0.00 & 0.91 & 3.24 & 7.11 & \\
\hline \multirow[t]{2}{*}{ Scenedesmacae } & Scenedesmus & 0.00 & 0.02 & 0.04 & 0.00 & \\
\hline & Crucigenia & 12.37 & 7.36 & 15.99 & 29.61 & \\
\hline \multirow[t]{19}{*}{ Diatomophycae } & Melosira & 20.10 & 19.91 & 27.99 & 23.65 & \\
\hline & Stephanodiscus & 0.00 & 0.01 & 0.09 & 1.24 & \\
\hline & Cyclotella & 3.26 & 3.17 & 3.29 & 3.18 & \\
\hline & Cocconeis & 0.34 & 0.17 & 0.61 & 1.56 & \\
\hline & Frustulia & 0.69 & 0.58 & 0.68 & 1.61 & \\
\hline & Gyrosigma & 0.00 & 2.98 & 3.87 & 1.00 & \\
\hline & Navicula & 0.14 & 1.04 & 0.92 & 0.74 & \\
\hline & Cymbella & 0.00 & 0.20 & 0.08 & 0.31 & \\
\hline & Amphora & 0.00 & 0.13 & 0.50 & 1.04 & \\
\hline & Fragilaria & 0.00 & 0.06 & 0.06 & 0.06 & \\
\hline & Nitztchia & 0.21 & 0.10 & 0.17 & 0.00 & \\
\hline & Campylodiscus & 0.00 & 0.04 & 0.03 & 0.05 & \\
\hline & Gomphonema & 0.00 & 0.08 & 0.00 & 0.00 & \\
\hline & Epithemia & 0.00 & 0.00 & 0.19 & 0.00 & \\
\hline & Diatoma & 0.00 & 0.00 & 0.00 & 0.06 & \\
\hline & Synedra & 0.00 & 0.00 & 0.03 & 0.00 & \\
\hline & Achnanthes & 0.00 & 0.05 & 0.02 & 0.00 & \\
\hline & Closterium & 0.00 & 0.06 & 0.00 & 0.00 & \\
\hline & Anomoconeis & 0.00 & 0.10 & 0.00 & 0.00 & \\
\hline \multirow[t]{2}{*}{ Chlorococcacae } & Dictyosphaerium & 0.00 & 0.00 & 0.03 & 0.00 & \\
\hline & Coelosphaerium & 0.69 & 2.19 & 1.43 & 0.14 & \\
\hline Desmidiacae & Euastrum & 0.00 & 0.07 & 0.00 & 0.00 & \\
\hline Peridiniacae & Peridinium & 0.00 & 0.05 & 0.00 & 0.00 & \\
\hline Protozoan & Stentor & 0.00 & 0.02 & 0.00 & 0.00 & \\
\hline Sand grains & & 26.80 & 22.09 & 24.84 & 17.18 & \\
\hline Detritus & & 0.00 & 1.80 & 1.52 & 0.62 & \\
\hline Unidentified preys & & 4.47 & 2.96 & 0.14 & 0.47 & - \\
\hline Number of individuals & & 23 & 313 & 248 & 45 & 1 \\
\hline Niche breadth & & 4.54 & 5.44 & 5.78 & 5.47 & - \\
\hline
\end{tabular}

As a result, C. gasar colonizes various brackish habitats of temperate to sub-tropical environments and are found abundantly in seashores, shallow bays, lagoons, estuaries, and coastal waters [44-46]. This trophic plasticity behavior probably results from the specialized morphological structure of C. gasar, mainly the presence of gills which facilitate the filtering of numeric phytoplankton [31].

Among the sample examined, $20.16 \%$ (127 specimens) had empty stomach while $79.84 \%$ (503 specimens) had food in their stomach. The relatively high percentage of empty stomach may reflect reduced feeding intensity. In- 
deed, sampling was accomplished during high-water season with relatively high water flow and disturbances. Consequently, the oysters may partially or totally close their valves to resist to the external pressure from flow velocity, affecting food intake and lead to reduced stomach fullness or an increase in the number of empty stomachs $[47,48]$.

Discrimination of the nutritional quality of ingested foods: Crassostrea species are sessile epibenthic bivalves confined to the bottom and not capable to move for foraging $[31,49]$. Probably, to adapt to this benthicmuddy environment and to increase survival, this species has evolved a specialized feeding mechanism and strategy to retrieve only needed nutrients for growth and development and to reject awful and non-digestible foods. As reported by Newell \& Jordan and Newell \& Langdon [31,32], by active selection, oysters are able to sort organic material by size before ingestion while rejecting inorganic particles. Baldwin \& Newell and Baldwin [50, 51] reported that many bivalves like Crassostrea are able to discriminate the nutritional quality of preys and sort foods according to their nutritional needs. Consequently, non-nutritious particles are sorted and rejected before entering the gut, while nutritious foods are retained in the stomach and undergo digestion process.

In this study, despite the proximity of the rearing ground to the grassroots houses causing a permanent discharge of domestic waste, C. gasar exhibited a relatively high growth rate $(2.14 \mathrm{~mm} / \mathrm{month})$ and low mortality $(<2 \%)$. This is partially due to the foraging strategy and behavior allowing selective food intake which guaranties species survival and rapid growth.

Modification of food web structure: At the oyster rearing grounds, there is evidence of probable modification of the food web structure compared to the others sites of the Benin coastal zone. This was shown by the intense multi-species fisheries activity taking place at the rearing grounds and targeted to crabs (Callinectes $s p$ ), shrimps (Penaeus $s p$ ) and fish species like Sarotherodon melanotheron, Tilapia sp, Liza falcipinis, Mugil curema, Dormitator lebretonis, Eleotris sp, Ethmalosa fimbriata, Gerres sp, Clarias gariepinis etc. Indeed, as reported by Newell\&Langdon [32], during feeding, Crassostrea reject excess amounts or unsuitable filtered foods called pseudo feces which could sink lagoon bottom to directly supply a nutritional food source to several deposit-feeders and to modify benthic features. Also, the resuspended pseudo feces in the water column are remineralized into nutrients to generate phytoplankton bloom. This food resource availability causes the concentration of many organisms (shrimps, crabs, fish etc.) at the oyster rearing grounds, thus, in addition to the change in bottom characteristics, leads to a shift in the food web structure [52, 53]. As reported by White \& Wilson and Milewski \&
Chapman [54,55], oyster beds provide refuges and feeding grounds for various coastal organisms such as fish crustaceans, mollusks, worms etc., and many predators are found among these organisms feeding on different sizes of oysters.

\section{CONCLUSION}

This study gives quantitative and qualitative information on the feeding ecology of C. gasar at the Benin coastal lagoons. C. gasar is a filter-feeder, foraging mainly on various taxa of phytoplankton and exhibiting an ontogenetic diet shift. This shellfish showed a broader niche breadth with a degree of trophic plasticity which enables $C$. gasar to colonize various coastal habitats, such as seashores, shallow bays, lagoons, estuaries, coastal waters, degraded and fragmented mangrove habitats and to successively sustain various aquaculture milieus. To adapt to its confined benthic-muddy environment, C. gasar has evolved a specialized feeding mechanism and strategy to retrieve needed nutrients and to reject awful and non-digestible foods. Probably, the establishment of the oyster at the rearing grounds positively modifies the food web structure of the rearing sites of the coastal zone. The output from this investigation will form a valuable documentation for the sustainable development of oyster aquaculture, wild stock management and conservation. However, further scientific knowledge on nutritional needs, phytoplankton toxicity and habitat degradation, and improvement of farming methods are required for an integrated oyster management at the Benin costal areas.

\section{ACKNOWLEDGEMENTS}

We thank the "Département de Zoologie, Faculté des Sciences et Techniques, Université d’Abomey-Calavi” for its assistance. We are grateful to the women association of traditional oyster farming of Degoue village for helping during the rearing period. I express my gratitude to the numerous reviewers for their thorough peer-review of this manuscript and helpful insights.

\section{REFERENCES}

[1] South Australian Oyster Research Council (2010) The best oysters are pure: Nutritional facts, vitamins and mineral. http://www.coffinbayoysters.com.au

[2] FAO (1982) Coastal aquaculture development perspectives in Africa and case studies from other regions. CIFA Technical Paper, CIFA/CPCA/T9.

[3] Abiogba, O.E. and Henadou J. (2006) Contribution à l'étude des huîtres exploitées au lac Nokoué: Etat des lieux. Mémoire pour l'obtention du Diplôme d'Etude Agricole Tropicale, LAMS, Sékou.

[4] Adite, A., Abou, Y., Sossoukpê, E. and Fiogbe, D.E. (2013) The oyster farming in the coastal ecosystem of Southern Benin (West Africa): Environment, growth and contribu- 
tion to sustainable coastal fisheries management. International Journal of Development Research, 3, 87-94.

[5] FAO (1976) Conférence technique de la FAO sur l'aquaculture, Kyoto, Japon, 26 Mai - 2 Juin 1976. Rapport FAO Pêches, No. 188.

[6] NOAA (2013) PMEL carbon program. http://www.pmel.noaa.gov/co2/story/What+is+Ocean+Ac idification $\% 3 \mathrm{~F}$

[7] Global Biodiversity Information Facility (2013) GBIF backbone taxonomy. http://www.gbif.org/species/2286068

[8] Miossec, L., Le Deuff, L. R.-M. and Goulletquer, P. (2009) Alien species alert: Crassostrea gigas (Pacific oyster). ICES Cooperative Research Report, No. 299, Copenhagen.

[9] Abgrall, M.-J., Bastien-Daigle, S., Miron, G. and Ouellette, M. (2010) Potential interactions between populations of Softshell Clams (Mya arenaria) and Eastern Oysters (Crassostrea virginica) in temperate estuaries, a literature review. Canadian Technical Report of Fisheries and Aquatic Sciences, No. 2892.

[10] PAZH (1999) Rapport sur le programme d’aménagement des Zones Humides. PAZH-MDR, Cotonou.

[11] Adite, A., Kinkpe, R. K., Sossa, G. N., and Viaho, C. C. (2005) Données préliminaires sur l'ostréiculture traditionnelle à la lagune côtière du Bénin (West-Africa). Technical Report, PRECOB/FAST/UAC, Abomey-Calavi.

[12] GCLME (2006) Guinea current large marine ecosystem report. GEF/UNIDO/UNDP/UNEP/US-NOAA, Cotonou.

[13] Diedhiou, M. (2008) Contribution à l'étude de la qualité bactériologique des huîtres fraiches dans l'aire marine protégée du petit Kassa (Casamance). Mémoire de DESS Pêche-Aquaculture, Université Cheikh Anta Diop, Dakar.

[14] Quayle, D.B. (1980) Les huîtres sous les tropiques: Culture et Méthode. I.D.R.C., Ottawa.

[15] PADPPA (2010) Elaboration de la politique nationale des pêches et de l'aquaculture. Rapport final, PADPPA, Cotonou.

[16] Morton, J.E. (1958) Mollusks: An introduction to their form and functions. Harper and Brothers Editor, New York.

[17] Aron, M. and Grasse, P.P. (1962) Biologie animale. Edition Masson et Compagnie.

[18] Mallet, N. (2005) Ecologie alimentaire de l'huître Crassostrea gigas: Dynamiques des compositions isotopiques naturelles. Thèse de Doctorat, Université de La Rochelle.

[19] Boehs, G., Lenz, T.M. and Villalba, A. (2009) Xenomas in Crassostrea rhizophorae (Ostreidae) from Camamu Bay, Bahia, Brazil. Brazilian Journal of Biology, 69, 457-458. http://dx.doi.org/10.1590/S1519-69842009000200032

[20] Akoegninou, A., Oyede, L.M. and Toffi, M. (1993) La mangrove du Benin: Environnement physique, végétation, et essais de gestion. Document technique No 2, FAST-UNB, Abomey-Calavi.

[21] Needham, G.J. and Needham, P.R. (1962) A guide to the study of fresh-water biology. Holden Day, San Francisco, California.
[22] Winemiller, K.O. (1989) Ontogenetic diet shifts and resource partitioning among piscivorous fishes in the Venezuelan llanos. Environmental Biology of Fishes, 26, 177199. http://dx.doi.org/10.1007/BF00004815

[23] Simpson, E.H. (1949) Measurement of diversity. Nature, 163, 688. http://dx.doi.org/10.1038/163688a0

[24] Krebs, C.J. (1989) Ecological Methodology. Harper \& Row Publisher, New York.

[25] Morgan, G.A. Grieggo, O.V. and Gloeckner, G.W. (2001) SPSS for windows: An introduction to use and interpretation in research. Lawrence Erlbaum Associates, Publishers, Mahwah, New Jersey.

[26] Pianka, E.R. (1994) Evolutionary ecology. 5th Edition, Harper Collins College Publishers, New York.

[27] Winemiller, K.O. and Kelso-Winemiller, L.C. (2003) Food habits of tilapiine cichlids of the Upper Zambezi River and floodplains during the descending phase of the hydrological cycle. Journal of Fish Biology, 63, 120-128. http://dx.doi.org/10.1046/j.1095-8649.2003.00134.x

[28] Adite, A. (2007) Ecologie de Heterotis niloticus (Osteoglossiforme: Osteoglossidae) du Système fluvio-lacustre rivière Sô-lac Hlan (Sud-Bénin): Conservation et Intérêt pour l'aquaculture. Ph.D. Dissertation, Faculté des Scienes et Techniques, Université d'Abomey-Calavi, AbomeyCalavi,

[29] Nunoo, F.K.E., Sossoukpe, E., Adite, A. and Fiogbe, D.E. (2013) Foods habits of two species of Pseudotolithus (scianidae) off (West Africa) near shore waters and implications for management. International Journal of Fisheries and Aquaculture, 5, 142-151.

[30] Jimoh, A.A., Clarke, E.O., Whenu, O.O. and Adeoye, H.B. (2011) Foods and feeding habits of the African river prawn (Macrobrachim vollenhovenii, Herklots, 1857) in the Epe Lagoon, southwest Nigeria. International Journal of Fisheries and Aquaculture, 3, 10-15.

[31] Newell, R.I.E. and Jordan, S.J. (1983) Preferential ingestion of organic material by the American oyster Crassostrea virginica. Marine Ecological Progress Series, 13, 47-53. http://dx.doi.org/10.3354/meps013047

[32] Newell, R.I.E. and Langdon, C.J. (1996) Mechanisms and physiology of larval and adult feeding. In: Kennedy, V.S., Newell, R.I.E. and Eble, A.F., Eds., The Eastern Oyster Crassostrea virginica, Maryland Sea Grant College, College Park, Maryland, 185-229.

[33] Jordan, S.J. (1987) Sedimentation and remineralization associated with biodeposition by the American oyster Crassostrea virginica (Gmelin). Ph.D. Thesis, University of Maryland, Maryland.

[34] Zimmer-Faust, R.K. and Tamburri, M.N. (1994) Chemical identity and ecological implications of a waterborne, larval settlement cue. Limnology and Oceanography, 39, 1075-1087. http://dx.doi.org/10.4319/lo.1994.39.5.1075

[35] Adite, A., Winemiller, K.O. and Fiogbe, D.E. (2005) Ontogenetic, seasonal, and spatial variation in the diet of Heterotis niloticus (Osteoglossiformes; Osteoglossidae) in the Sô River-Lac Hlan system, Benin, West Africa. Environmental Biology of Fishes, 3, 367-378. http://dx.doi.org/10.1007/s10641-004-5563-9 
[36] Adriaens, D., Aerts, P. and Verraes, W. (2001) Ontogenetic shift in mouth opening mechanisms in a catfish (Clariidae, Siluriformes): A response to increasing functional demands. Journal of Morphology, 247, 197-216.

http://dx.doi.org/10.1002/1097-4687(200103)247:3<197:: AID-JMOR1012>3.0.CO;2-S

[37] Claessen, D., Van Oss, C., De Roos, A.M. and Persson, L. (2002) The impact of size-dependent predation on population dynamics and individual life history. Ecology, 83, 1660-1675. http://dx.doi.org/10.1890/0012-9658(2002)083[1660:TIO SDP]2.0.CO;2

[38] Koen Alonso, M., Crespo, E.A., Garcia, N.A., Pedraza, S.N., Mariotti, P.A. and Mora, N.J. (2002) Fishery and ontogenetic driven changes in the diets of the spiny dogfish, Squalus acanthias, in Patagonian waters, Argentina. Environmental Biology of Fishes, 63, 193-202. http://dx.doi.org/10.1023/A:1014229432375

[39] Steingrimsson, S.O. and Gislason, G.M. (2002) Body size, diet and growth of landlocked Brown Trout, Salmon trutta, in the subarctic River Laxa, North-East Iceland. Environmental Biology of Fishes, 63, 417-426. http://dx.doi.org/10.1023/A:1014976612970

[40] Barbarino Duque, A. and Winemiller, K.O. (2003) Dietary segregation among large catfishes of the Apure and Arauca Rivers, Venezuela. Journal of Fish Biology, 63, 410-427.

http://dx.doi.org/10.1046/j.1095-8649.2003.00163.x

[41] Garcia-Berthou, E. (1999) Food of introduced mosquitofish: Ontogenetics diet shift and prey selection. Journal of Fish Biology, 55, 135-147. http://dx.doi.org/10.1111/j.1095-8649.1999.tb00663.x

[42] Garcia-Berthou, E. and Moreno-Amich, R. (2000) Food of introduced pumpkinseed sunfish: Ontogenetic diet shift and seasonal variation. Journal of Fish Biology, 57, 29-40. http://dx.doi.org/10.1111/j.1095-8649.2000.tb00773.x

[43] Bowen, S.H. and Allanson, B.R. (1982) Behavioral and trophic plasticity of juvenile Tilapia mossambica in utilization of the unstable littoral habitat. Environmental Biology of Fishes, 7, 357-362. http://dx.doi.org/10.1007/BF00005570

[44] Steward, K.D. (2005) The American oyster. Underwater world 14, Fisheries and Oceans, Canada.

[45] Shumway, S. (1996) Natural environmental factors. In:
Kennedy, V.S., Newell, R.I.E. and Eble, A.F., Eds., The Eastern Oyster Crassostrea virginica. Maryland Sea Grant College, College Park, 467-513.

[46] Thompson, R.J., Newell, R.I.E., Kennedy, V.S. and Mann, R. (1996) Reproductive processes and early development. In: Kennedy, V.S., Newell, R.I.E. and Eble, A.F., Eds., The Eastern Oyster Crassostrea virginica, Maryland Sea Grant College, College Park, 335-370.

[47] Wildish, D.J. and Saulnier, A.M. (1993) Hydrodynamic control of filtration in the giant scallop. Journal of Experimental Marine Biology and Ecology, 174, 65-82. http://dx.doi.org/10.1016/0022-0981(93)90251-I

[48] Wildish, D. and Kristmanson, D. (1997) Mechanisms of seston capture and benthic populations and flow. In: Wildish, D. and Kristmanson, D., Eds., Benthic Suspension Feeders and Flow, Cambridge University Press, Cambridge, 270-312.

[49] Kennedy, V.S., Newell, R.I.E. and Eble, A.F. (1996) The eastern oyster Crassostrea virginica, Maryland Sea Grant College, College Park.

[50] Baldwin, B. S. and Newell, R.I.E. (1991) Omnivorous feeding by plantotrophic larvae of the Eastern Oyster Crassostrea virginica. Marine Ecological Progress Series, 78, 285-301.

[51] Baldwin, B.S. (1995) Selective particles ingestion by oyster larvae (Crassostrea virginica) feeding on natural seston and cultured algae. Marine Biology, 123, 95-107. http://dx.doi.org/10.1007/BF00350328

[52] Newell, C.R. (1979) Food Resources and Energy Partitioning. In: Newell, C.R., Ed., Biology of intertidal animals, Marine Ecological Surveys Ltd., Faversham, 331389.

[53] Haven, D. and Morales-Alamo, R. (1966) Aspects of biodeposition by oysters and other invertebrate filter feeders. Limnology and Oceanography, 11, 487-498. http://dx.doi.org/10.4319/lo.1966.11.4.0487

[54] White, M.E. and Wilson, E.A. (1996) Predators, pests, and competitors. In: Kennedy, V.S., Newell, R.I.E. and Eble, A.F., Eds., The Eastern Oyster Crassostrea virginica, Maryland Sea Grant College, College Park, 559-579.

[55] Milewski, I. and Chapman, S. (2002) Oysters in New Brunswick: More than a harvestable resource. Conservation Council of New Brunswick, Fredericton, NB. 